\title{
Effect of followed production procedures on the physicochemical properties of labneh anbaris
}

\section{Ossama Dimassi ${ }^{1^{*}}$, Youmna Iskandarani ${ }^{2}$, Raymond Akiki ${ }^{1}$}

\author{
${ }^{1}$ American University of Europe, Skopje, North-Macedonia \\ ${ }^{2}$ Department of Nutrition and Food Science, Lebanese International University, Beirut, Lebanon \\ *Corresponding author
}

Received: 15 Oct 2020; Received in revised form: 9 Nov 2020; Accepted: 11 Nov 2020; Available online: 17 Nov 2020

\begin{abstract}
The aim of this study is to assess the different recorded processing attributes on physicochemical properties of anbaris and comparing them to commercially produced labneh done from pasteurized cow and goat milk. Comparing the industrially produced IP-anbaris with labneh industrially produced using cows and goat milk showed that the cow-labneh possessed significantly lower total-solids, titratable acidity, salt, ash, fat and protein content while having significantly higher $\mathrm{pH}$ and moisture content. As for the house hold produced anbaris, it was categorized into two classes according to the behavior of the household producer. Produced but in-between partial consumption of anbaris from the earthen-vessel and refilling during the process; HHC-anbaris; and produced but consumed only towards the end; HH-anbaris. Interestingly, the IP-anbaris compared to HHC-anbaris values did not differ significantly in any physicochemical property except in water activity, being significantly lower, and in titratable acidity, being significantly higher. As for the HH-anbaris, it possessed the significantly lowest water activity and protein content and the significantly highest titratable acidity compared to those recorded for IP- and HHC-anbaris. Traditionally earthenware-vessel was used in anbaris production but glass-vessel was recently introduced. In this study, there was no significant difference in the physicochemical properties between earthenware-anbaris or glass-vessel-anbaris. Furthermore, studying the characteristics of anbaris within the vessel before it is mixed showed that the bottom part was the significantly highest in total solids, fat and ash content compared to anbaris taken from the middle and upper section whose physicochemical properties did not differ significantly from each other.
\end{abstract}

Keywords-Anbaris, Labneh, Earthen vessel, Water activity, Industrial, House hold.

\section{INTRODUCTON}

Through the history, fermentation was mainly used to preserve food, longer shelf life, while being oblivion to the beneficial effects on health. This lead to fermented food being an integral parts of diet in many cultures [1] [2] [3]. Recently, product resulting from food fermentation microorganisms has been associated with health benefits [4]. During fermentation Lactic acid bacteria, one of the most studied microorganisms, synthesize vitamins and minerals, produce biologically active peptides with enzymes such as proteinase and peptidase, and remove some non-nutrients [5] [4]. Examples of health benefits are anti-oxidant, anti-microbial, anti-fungal, antiinflammatory, anti-diabetic and anti-atherosclerotic activity products [4].
Labneh Anbaris, a traditional cheese-like fermented dairy product, is usually prepared from cow's and goat's milk following natural fermentation of raw milk in earthen vessel at around $30^{\circ} \mathrm{C}$ for $7-15$ days after which the whey is drained and raw milk plus salt is added repeatedly until the earthenware vessel is full [6] [7]. Since raw milk is traditionally used, no starter culture is added nor $\mathrm{CaCl} 2$ solution to assist curdling of milk [8] [9]. Traditionally, anbaris production is during spring till the end of the summer [7]. The end product is recovered in September as a very concentrated and highly acidic type of Labneh. It is consumed fresh or made into small balls and submerged in vegetable oil in jars to be consumed later [6].

Anbaris is a special type of full fat, soft, cheese like fermented cheese produced from raw milk with a $\mathrm{pH}$ lower than 4. It is special since it is fermented with no addition 
of culture, whey strained, earthen vessel refilled with milk and salt added then left again [10] [6] [7]. It is relatively safe against bacterial contamination but not yeast and mold especially if high moisture content anbaris is produced [10]. It can be used to reduce wastage of extra milk or milk that have reached $6.4 \mathrm{in} \mathrm{pH}$ thus out of the normal range. [10]

While exploring labneh anbaris production and physicochemical properties in Lebanon [10]. Furthermore, some minor differences were recorded in production such as usage of pasteurized milk instead of unpasteurized one, usage of glass vessel for fermentation instead of earthen vessel. In addition to that, some people would partially consume some of the anbaris after 7-15 days and fill again while others would wait till the whole earthen vessel is full with anbaris. All of these factors were the incentive to conduct this research to compare anbaris to the commercially produced labneh made from cow and goat milk. Also to register if the physicochemical properties are influenced by the change of the input product (raw milk), fermentation container (Glass or earthen vessel), household behavior (consumption during production or not). Last but not least, the profile of anbaris produced in the vessel - top versus bottom- was studied.

\section{MATERIALS AND METHODS}

\subsection{Sampling procedure}

\subsubsection{Industrial anbaris samples}

The industrial anbaris samples were divided into two categories according to milk pretreatment, Industrialpasteurized (9 samples) and industrial-non-pasteurized (12 samples). Since there was no significant difference the pasteurized and the non-pasteurized industrially produced anbaris samples were all called Industrially produced (IP) Anbaris (21 samples).

\subsubsection{House Hold Anbaris Samples}

The house hold anbaris samples were divided according to the behavior of the house hold producers. Produced but inbetween partial consumption of anbaris from the earthenvessel and refilling during the process; HHC-anbaris (36); and produced but consumed only towards the end; HHanbaris (21).

\subsubsection{Samples of anbaris from different levels of earthen vessel and anbaris done in glass vessel}

Six earthen vessels were used to produce anbaris labneh. From each earthen vessel samples were taken from three positions being the top $15 \mathrm{~cm}-$, the middle $15 \mathrm{~cm}$ and the bottom $15 \mathrm{~cm}$ (Fig. 1) having around 20 liters volume. Top being the farthest from the drainage hole and bottom being at the level of the drainage hole.

Six glass vessels 20 liter each, similar to that of the earthen vessel (Fig. 1) were used to produce anbaris labneh.

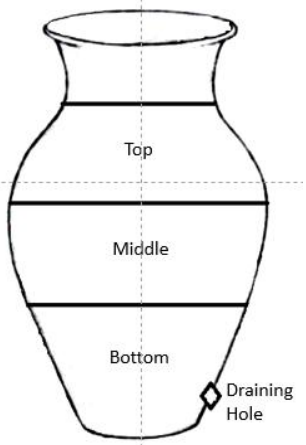

Fig.1 Earthen Vessel Sketch

\subsubsection{Samples of anbaris compared to labneh produced} from cow and goat milk

To compare anbaris to labneh from cows and goat milk, two companies, out of the 7 anbaris producing companies ((Dimassi, 2020 \#555), agreed to provide us with 18 samples, from different lots, of cow, goat and anbaris labneh each.

\subsection{Physico-chemical properties}

Moisture content: Drying Oven and Balance method was used for moisture content determination. The oven used was Contherm designer series (Contherm Scientific LTD) following the ISO 5537:2004 [11].

Fat Determination: The fat content was determined using Soxhlet method as described by AOAC 922.06. [12]

Protein Determination: Protein content was determinedusing the Kjeldahl method according to AOAC 991.20. [12]

Ash Determination: Ash was determined using the AOAC 942.05 method. [12]

Weight determination: Weight was measured using Portable electronic balance Model 727 was used to measure the weight with an accuracy of \pm 1 gr (Jata Hogar).

pH: Microcomputer based pH /conductivity /TDS /salinity and temperature pocket meter Model pH/EC80 was used to measure the $\mathrm{pH}$ (Jenco VisionP).

Titratable Acidity: TA is expressed as percent lactic acid and is determined by titration of a known amount of reconstituted milk with $0.1 \mathrm{~N} \mathrm{NaOH}$ using phenolphthalein as indicator [13]. 
Water activity: It was determined using Lab Start-aw water activity meter from novasina. Samples were flattened to cover the bottom of the cup and then water activity was measured at room temperature [14].

Salt: It was determined using Chloride QuanTab® Test Strips, 30-600 mg/L, Hach Company, Loveland, Colorado USA [15].

\subsection{Statistical analysis}

All tests and analysis were run in triplicates. General linear model performed via SPSS (statistical Package for the Social Sciences, version 17.0) was used to study the difference between the physicochemical properties and the score of the sensory attributes of the four different products. To study the difference between the physicochemical properties of the anbaris based on sample origion. Tamhane test was used for mean separation of the physicochemical properties.

\section{RESULTS}

\subsection{Physicochemical values of the Industrially produced,} house hold produced and house hold produced but with consumption anbaris

3.1.1 Water Activity (aw), moisture and total solids

The aw of anbaris did differ significantly where the water activity of the lowest for the $\mathrm{HH}$-anbaris and significantly the highest for the IP-anbaris with the HHC-anbaris being in the middle (Table 1).

All for the moisture and the total solids content there was no significant differences between the values recorded for IP-, and HHC- anbaris, while the values of the HH-anbaris was significantly the highest (Table 1).

Table-1 Water activity (aw), moisture and total solids (TS) of anbaris from different origins

\begin{tabular}{lccc}
\hline & Aw & $\begin{array}{c}\text { Moisture } \\
(\mathrm{g} / 100 \mathrm{gr})\end{array}$ & $\begin{array}{c}\text { TS } \\
(\mathrm{g} / 100 \mathrm{gr})\end{array}$ \\
\cline { 2 - 4 } & Mean $\pm \mathrm{SE}$ & Mean $\pm \mathrm{SE}$ & Mean $\pm \mathrm{SE}$ \\
\hline IP-anbaris & $0.969 \mathrm{a}$ & $62.462 \mathrm{a}$ & $37.537 \mathrm{a}$ \\
& \pm 0.002 & \pm 1.993 & \pm 1.992 \\
HH- & $0.954 \mathrm{~b}$ & $66.370 \mathrm{~b}$ & $33.620 \mathrm{~b}$ \\
anbaris & \pm 0.002 & \pm 1.845 & \pm 1.854 \\
HHC- & $0.962 \mathrm{c}$ & $61.457 \mathrm{a}$ & $38.457 \mathrm{a}$ \\
anbaris & \pm 0.001 & \pm 1.495 & \pm 1.500 \\
\hline
\end{tabular}

- Within Columns, means with different alphabets are significantly different.

- IP: Industrial Produced, HH: House Hold, C: With consumption;

\subsection{2 $\mathrm{pH}$, titratable acidity and salt}

The $\mathrm{pH}$ values all were lower than 3.8 thus they are in the high acid product category $(\mathrm{pH}<4.6)$ and there was no significant difference between the $\mathrm{pH}$ values of IP-, HHand HHC- anbaris (Table 2).

As for the titratable acidity (TA) $\mathrm{HH}$-anbaris possessed the significantly highest value followed by that of HHCanbaris with the TA values of the IP-anbaris being the significantly lowest. (Table 2).

Concerning the salt concentration, the IP-anbaris had the significantly lowest salt value while the values of the $\mathrm{HH}$ anbaris and those of the HHC-anbaris did not differ significantly (Table 2).

Table-2 pH, titratable acidity(TA) and salt content of anbaris from different origins

\begin{tabular}{lccc}
\hline & $\mathrm{pH}$ & $\begin{array}{c}\text { TA } \\
(\mathrm{g} / 100 \mathrm{gr})\end{array}$ & $\begin{array}{c}\text { Salt } \\
(\mathrm{g} / 100 \mathrm{gr})\end{array}$ \\
\cline { 2 - 4 } & Mean $\pm \mathrm{SE}$ & Mean $\pm \mathrm{SE}$ & Mean $\pm \mathrm{SE}$ \\
\hline IP-anbaris & $3.709 \mathrm{a}$ & $4.025 \mathrm{a}$ & $1.949 \mathrm{a}$ \\
& \pm 0.051 & \pm 0.208 & \pm 0.212 \\
HH- & $3.646 \mathrm{a}$ & $5.739 \mathrm{~b}$ & $2.729 \mathrm{~b}$ \\
anbaris & \pm 0.047 & \pm 0.192 & \pm 0.196 \\
HHC- & $3.607 \mathrm{a}$ & $4.736 \mathrm{c}$ & $2.636 \mathrm{~b}$ \\
anbaris & \pm 0.038 & \pm 0.156 & \pm 0.159 \\
\hline
\end{tabular}

- Within Columns, means with different alphabets are significantly different.

- IP: Industrial Produced, HH: House Hold, C: With consumption;

\subsubsection{Fat, protein and ash content}

The Fat content and the ash content of the IP-, HH- and HHC-anbaris, did not differ significantly from each other (Table 3).

As for the protein content the HH-anbaris had the significantly lowest value while their was no significant difference between the protein content values of IP- and HHC-anbaris (Table 3). 
Table-3 Fat, protein and ash content of anbaris from different origins

\begin{tabular}{lccc}
\hline & $\begin{array}{c}\text { Fat } \\
(\mathrm{g} / 100 \mathrm{gr})\end{array}$ & $\begin{array}{c}\text { Protein } \\
(\mathrm{g} / 100 \mathrm{gr})\end{array}$ & $\begin{array}{c}\text { Ash } \\
(\mathrm{g} / 100 \mathrm{gr})\end{array}$ \\
\cline { 2 - 4 } & Mean $\pm \mathrm{SE}$ & Mean $\pm \mathrm{SE}$ & Mean $\pm \mathrm{SE}$ \\
\hline IP-anbaris & $19.756 \mathrm{a}$ & $18.557 \mathrm{a}$ & $5.786 \mathrm{a}$ \\
& \pm 0.051 & \pm 0.208 & \pm 2.049 \\
HH- & $17.486 \mathrm{a}$ & $13.118 \mathrm{~b}$ & $6.009 \mathrm{a}$ \\
anbaris & \pm 0.047 & \pm 0.192 & \pm 1.897 \\
HHC- & $20.226 \mathrm{a}$ & $19.007 \mathrm{a}$ & $8.096 \mathrm{a}$ \\
anbaris & \pm 0.038 & \pm 0.156 & \pm 1.536
\end{tabular}

- Within Columns, means with different alphabets are significantly different.

- IP: Industrial Produced, HH: House Hold, C: With consumption;

\subsection{Physicochemical properties of Anbaris at different levels of Earthen Vessel}

When the earthen vessel was full with anbaris samples were taken from 6 earthen vessels with 3 samples from each level (Fig. 1)

3.2.1 Water activity, moisture content and total solids

There was no significant difference in the water activity values of anbaris taken from the three different level. This was, however, different when the moisture content of the anbaris samples taken at the three levels. The samples of anbaris taken at the bottom showed the significantly lowest moisture content and consequently the significantly highest total solids (Table 4).

Table-4 Water activity (aw), moisture and total solids

(TS) of anbaris from different earthen vessel levels

\begin{tabular}{lccc}
\hline \begin{tabular}{c} 
Position in $\begin{array}{c}\text { Earthen- } \\
\text { Vessel }\end{array}$ \\
\cline { 2 - 4 } Top
\end{tabular} & Mean \pm SE & $\begin{array}{c}\text { Moisture } \\
(\mathrm{g} / 100 \mathrm{gr})\end{array}$ & $\begin{array}{c}\text { TS } \\
(\mathrm{g} / 100 \mathrm{gr})\end{array}$ \\
& $0.931 \mathrm{a}$ & $77.111 \mathrm{a}$ & $22.879 \mathrm{a}$ \\
& \pm 0.001 & \pm 1.531 & \pm 1.490 \\
Middle & $0.931 \mathrm{a}$ & $74.501 \mathrm{a}$ & $25.488 \mathrm{a}$ \\
& \pm 0.001 & \pm 1.531 & \pm 1.541 \\
Bottom & $0.927 \mathrm{a}$ & $67.787 \mathrm{~b}$ & $32.214 \mathrm{~b}$ \\
& \pm 0.001 & \pm 1.531 & \pm 1.500 \\
\hline
\end{tabular}

- Within Columns, means with different alphabets are significantly different.

\subsection{2 $\mathrm{pH}$, titratable acidity (TA) and salt content}

There was no significant difference in the ph, titratable acidity and the salt content of the anbaris sample taken from the top, middle and bottom levels of the earthen vessels (Table 5).

Table-5 pH, titratable acidity(TA) and salt content of anbaris from different earthen vessel levels

\begin{tabular}{lccc}
\hline $\begin{array}{c}\text { Position in } \\
\text { Earthen- }\end{array}$ & $\mathrm{pH}$ & $\begin{array}{c}\text { TA } \\
(\mathrm{g} / 100 \mathrm{gr})\end{array}$ & $\begin{array}{c}\text { Salt } \\
(\mathrm{g} / 100 \mathrm{gr})\end{array}$ \\
\cline { 2 - 4 } Vessel & Mean $\pm \mathrm{SE}$ & Mean $\pm \mathrm{SE}$ & Mean $\pm \mathrm{SE}$ \\
\hline \multirow{2}{*}{ Top } & $4.075 \mathrm{a}$ & $1.350 \mathrm{a}$ & $0.923 \mathrm{a}$ \\
& \pm 0.052 & \pm 0.098 & \pm 0.221 \\
Middle & $3.944 \mathrm{a}$ & $1.596 \mathrm{a}$ & $0.932 \mathrm{a}$ \\
& \pm 0.052 & \pm 0.098 & \pm 0.221 \\
Bottom & $3.976 \mathrm{a}$ & $1.536 \mathrm{a}$ & $0.977 \mathrm{a}$ \\
& \pm 0.052 & \pm 0.098 & \pm 0.221
\end{tabular}

- Within Columns, means with different alphabets are significantly different.

\subsubsection{Fat, protein and ash content}

Concerning fat, protein and ash content of the anbaris samples from the bottom level of the earthen vessel, were significantly the highest with those values from the middle and top position did not differ significantly (Table 6).

Table-6 Fat, protein and ash content of anbaris from different earthen vessel levels

\begin{tabular}{lccc}
\hline $\begin{array}{c}\text { Position in } \\
\text { Earthen- } \\
\text { Vessel }\end{array}$ & $\begin{array}{c}\text { Fat } \\
(\mathrm{g} / 100 \mathrm{gr})\end{array}$ & $\begin{array}{c}\text { Protein } \\
(\mathrm{g} / 100 \mathrm{gr})\end{array}$ & $\begin{array}{c}\text { Ash } \\
(\mathrm{g} / 100 \mathrm{gr})\end{array}$ \\
\cline { 2 - 4 } Mean \pm SE & Mean \pm SE & Mean \pm SE \\
\hline \multirow{2}{*}{ Top } & $7.818 \mathrm{a}$ & $10.316 \mathrm{a}$ & $1.755 \mathrm{a}$ \\
& \pm 1.011 & \pm 1.713 & \pm 0.123 \\
Middle & $6.667 \mathrm{a}$ & $13.927 \mathrm{a}$ & $1.907 \mathrm{a}$ \\
& \pm 1.011 & \pm 1.713 & \pm 0.123 \\
Bottom & $11.058 \mathrm{~b}$ & $15.742 \mathrm{~b}$ & $2.413 \mathrm{~b}$ \\
& \pm 1.011 & \pm 1.713 & \pm 0.123 \\
\hline
\end{tabular}

- Within Columns, means with different alphabets are significantly different.

3.3 Physicochemical properties of anbaris fermented and strained in glass vessel compared to that fermented and strained in earthen vessel

3.3.1 Water activity, moisture content and total solids 
There was no significant difference between the water water activity value of anbaris originated from glass vessel compared to that originating from earthen vessel (Table 7).

However, when comparing the moisture content and total solids values of both, anbaris done in glass vessel had a significantly higher moisture content and consequently a significantly lower total solids when compared to that done in earthen vessel (Table 7).

Table-7 Water activity (aw), moisture and total solids (TS) of anbaris from fermented and strained in glass and in earthen vessel

\begin{tabular}{lccc}
\hline Vessel & Aw & $\begin{array}{c}\text { Moisture } \\
(\mathrm{g} / 100 \mathrm{gr})\end{array}$ & $\begin{array}{c}\text { TS } \\
(\mathrm{g} / 100 \mathrm{gr})\end{array}$ \\
\cline { 2 - 4 } & Mean $\pm \mathrm{SE}$ & Mean $\pm \mathrm{SE}$ & Mean $\pm \mathrm{SE}$ \\
\hline \multirow{2}{*}{ Glass } & $0.968 \mathrm{a}$ & $70.963 \mathrm{a}$ & $29.038 \mathrm{a}$ \\
& \pm 0.003 & \pm 2.165 & \pm 2.165 \\
Earth/clay & $0.964 \mathrm{a}$ & $63.138 \mathrm{~b}$ & $36.862 \mathrm{~b}$ \\
& \pm 0.002 & \pm 1.531 & \pm 1.531 \\
\hline
\end{tabular}

- Within Columns, means with different alphabets are significantly different.

\subsection{2 $\mathrm{pH}$, titratable acidity (TA) and salt content}

The $\mathrm{pH}$ and titratable acidity of anbaris done using glass and earthen vessels did not differ significantly from each other. Salt, however, was significantly higher in anbaris samples done using glass vessel than those done using earthen vessel (Table 8).

Table- $8 \mathrm{pH}$, titratable acidity (TA) and salt content of anbaris from fermented and strained in glass and in earthen vessel

\begin{tabular}{lccc}
\hline \multicolumn{1}{c}{ Vessel } & $\mathrm{pH}$ & $\begin{array}{c}\text { TA } \\
(\mathrm{g} / 100 \mathrm{gr})\end{array}$ & $\begin{array}{c}\text { Salt } \\
(\mathrm{g} / 100 \mathrm{gr})\end{array}$ \\
\cline { 2 - 4 } & Mean $\pm \mathrm{SE}$ & Mean $\pm \mathrm{SE}$ & Mean $\pm \mathrm{SE}$ \\
\hline \multirow{2}{*}{ Glass } & $3.897 \mathrm{a}$ & $1.644 \mathrm{a}$ & $3.751 \mathrm{a}$ \\
& \pm 0.146 & \pm 0.201 & \pm 0.381 \\
Earth/clay & $3.693 \mathrm{a}$ & $1.737 \mathrm{a}$ & $2.028 \mathrm{~b}$ \\
& \pm 0.037 & \pm 0.142 & \pm 0.270 \\
\hline
\end{tabular}

- Within Columns, means with different alphabets are significantly different.

\subsubsection{Fat, protein and ash content}

The fat and ash content of anbaris samples done using glass vessels did not differ significantly from those values of anbaris processed using earthen vessels.
Table-9 Fat, protein and ash content of anbaris from fermented and strained in glass and in earthen vessel

\begin{tabular}{lccc}
\hline \multicolumn{1}{c}{ Vessel } & $\begin{array}{c}\text { Fat } \\
(\mathrm{g} / 100 \mathrm{gr})\end{array}$ & $\begin{array}{c}\text { Protein } \\
(\mathrm{g} / 100 \mathrm{gr})\end{array}$ & $\begin{array}{c}\text { Ash } \\
(\mathrm{g} / 100 \mathrm{gr})\end{array}$ \\
\cline { 2 - 4 } & Mean $\pm \mathrm{SE}$ & Mean $\pm \mathrm{SE}$ & Mean $\pm \mathrm{SE}$ \\
\hline \multirow{2}{*}{ Glass } & $20.997 \mathrm{a}$ & $11.841 \mathrm{a}$ & $5.522 \mathrm{a}$ \\
& \pm 0.146 & \pm 0.201 & \pm 0.381 \\
Earth/clay & $19.117 \mathrm{a}$ & $18.666 \mathrm{a}$ & $5.240 \mathrm{a}$ \\
& \pm 0.037 & \pm 0.142 & \pm 0.270 \\
\hline
\end{tabular}

- Within Columns, means with different alphabets are significantly different.

Protein content, however, did differ significantly, where samples of anbaris manufactured utilizing earthen vessel had significantly higher protein values compare to those manufactured using glass vessels (Table 9).

\subsection{Comparing physicochemical properties of anbaris to labneh (strained yogurt) done from cows and goat milk}

3.4.1 Water activity, moisture content and total solids

There was no recorded significant difference when comparing the water activity of anbaris with labneh, strained yogurt [16], produced using cow's and goat's milk (Table 10).

The picture is different, however, when we compare moisture and total solids content, where anbaris samples did not differ significantly from labneh done from goat milk, both being significantly different from labneh values done from cow's milk, whose moisture content was significantly the highest and consequently the total solid content was significantly the lowest (Table 10).

Table-10 Water activity (aw), moisture and total solids

(TS) of anbaris and labneh from cow and goat milk

\begin{tabular}{lccc}
\hline & Aw & $\begin{array}{c}\text { Moisture } \\
(\mathrm{g} / 100 \mathrm{gr})\end{array}$ & $\begin{array}{c}\text { TS } \\
(\mathrm{g} / 100 \mathrm{gr})\end{array}$ \\
\cline { 2 - 4 } & Mean $\pm \mathrm{SE}$ & Mean $\pm \mathrm{SE}$ & Mean $\pm \mathrm{SE}$ \\
\hline \multirow{2}{*}{ Anbaris } & $0.965 \mathrm{a}$ & $56.907 \mathrm{a}$ & $43.093 \mathrm{a}$ \\
& \pm 0.001 & \pm 2.375 & \pm 2.365 \\
G-labneh & $0.963 \mathrm{a}$ & $56.807 \mathrm{a}$ & $43.193 \mathrm{a}$ \\
& \pm 0.001 & \pm 2.375 & \pm 2.365 \\
C-labneh & $0.958 \mathrm{a}$ & $72.499 \mathrm{~b}$ & $27.551 \mathrm{~b}$ \\
& \pm 0.001 & \pm 2.375 & \pm 2.365 \\
\hline
\end{tabular}

- Within Columns, means with different alphabets are significantly different.

- C: Cow, G: Goat 


\subsection{2 $\mathrm{pH}$, titratable acidity (TA) and salt content}

The $\mathrm{pH}$ of anbaris did not differ significantly from the $\mathrm{pH}$ of labneh done from goat milk, both of which were significantly lower than $\mathrm{pH}$ of labneh done with cow's milk (Table 11).

Table-11 pH, titratable acidity (TA) and salt content of anbaris and labneh from cow and goat milk

\begin{tabular}{lccc}
\hline \multirow{7}{*}{ Anbaris } & $\mathrm{pH}$ & $\begin{array}{c}\text { TA } \\
(\mathrm{g} / 100 \mathrm{gr})\end{array}$ & $\begin{array}{c}\text { Salt } \\
(\mathrm{g} / 100 \mathrm{gr})\end{array}$ \\
& Mean $\pm \mathrm{SE}$ & Mean $\pm \mathrm{SE}$ & Mean $\pm \mathrm{SE}$ \\
\hline \multirow{2}{*}{ G-labneh } & $3.825 \mathrm{a}$ & $1.566 \mathrm{a}$ & $2.116 \mathrm{a}$ \\
& \pm 0.025 & \pm 0.062 & \pm 0.039 \\
& $3.868 \mathrm{a}$ & $1.602 \mathrm{a}$ & $2.290 \mathrm{a}$ \\
C-labneh & \pm 0.025 & \pm 0.062 & \pm 0.039 \\
& $4.093 \mathrm{~b}$ & $1.395 \mathrm{~b}$ & $1.670 \mathrm{~b}$ \\
& \pm 0.025 & \pm 0.062 & \pm 0.039 \\
\hline
\end{tabular}

- Within Columns, means with different alphabets are significantly different.

- C: Cow, G: Goat

As for the titratable acidity, the one recorded for anbaris was comparable to that of goat's milk labneh. Both being significantly higher than the titratable acidity value recorded for labneh produced from cow's milk.

The salt value of labneh from cow's milk had the significantly lowest salt content compared to anbaris and goat's milk labneh, while those values of both did not differ significantly.

Table-12 Fat, protein and ash content of anbaris and labneh from cow and goat milk

\begin{tabular}{lccc}
\hline & $\begin{array}{c}\text { Fat } \\
(\mathrm{g} / 100 \mathrm{gr})\end{array}$ & $\begin{array}{c}\text { Protein } \\
(\mathrm{g} / 100 \mathrm{gr})\end{array}$ & $\begin{array}{c}\text { Ash } \\
(\mathrm{g} / 100 \mathrm{gr})\end{array}$ \\
\cline { 2 - 4 } & Mean $\pm \mathrm{SE}$ & Mean $\pm \mathrm{SE}$ & Mean $\pm \mathrm{SE}$ \\
\hline Anbaris & $20.259 \mathrm{a}$ & $21.538 \mathrm{a}$ & $6.81 \mathrm{a}$ \\
& \pm 1.94 & \pm 0.062 & \pm 0.099 \\
G-labneh & $22.634 \mathrm{a}$ & $24.458 \mathrm{a}$ & $5.03 \mathrm{a}$ \\
& \pm 1.94 & \pm 0.062 & \pm 0.099 \\
C-labneh & $14.983 \mathrm{~b}$ & $10.892 \mathrm{~b}$ & $4.659 \mathrm{~b}$ \\
& \pm 1.94 & \pm 0.062 & \pm 0.099 \\
\hline
\end{tabular}

- Within Columns, means with different alphabets are significantly different.

- C: Cow, G: Goat

\subsubsection{Fat, protein and ash content}

Concerning the fat protein and ash content values, they were significantly the lowest for labneh produced using cow's milk compared to anbaris and goat's milk labneh, while the values recorded for both did not differ significantly.

\section{DISCUSSION}

Anbaris is a peculiar type of fermented cheese which is strained to get the peculiar gritty acidic taste [7] which is seemingly safe despite being done from raw milk [10] due to the low $\mathrm{pH}(<4)$ making it in the high acid food category [17]. Furthermore, there was no difference in the physicochemical properties of anbaris produced from pasteurized milk when compared to those produced from un-pasteurized milk. Nonetheless, sensory analysis should be done in another study since pasteurization lead to activation or inhibition of the plasmin/plasminogen complex, cathepsin D, lipoprotein lipase and alkaline phosphatase [18]. In addition to that, enzymes from psychrotrophic bacteria, acid phosphatase and xanthine oxidase, can survive pasteurization and may be active during ripening [18] while another array of enzymes will not survive. Also, it was noted that Lacto (a comparable fermented milk product in Zimbabwe) was less acceptable to the panelists when pasteurized milk was used compared to that produced from unpasteurized milk [19].

There is a difference between the industrially produced anbaris and that of the house hold produced anbaris. Interestingly the values of the house hold produced anbaris which is partially consumed during production, was very comparable to those from industrially produced anbaris. This might be explained by the fact that during production consumption is done from the top part (Fig. 1) of the earthen vessel before it is filled again with salt and milk were nearer to the industrially produced anbaris [10] [20]. Thus the significantly highest in moisture content and lowest in total solids will be consumed leading to more filling and draining times and thus higher total solid anbaris. In addition to that, the bottom part of anbaris is nearer to the draining hole and thus the higher protein and total solid content.

Comparing the physicochemical properties of anbaris produced using glass vessel and those produced using earthen vessel gave weight to the assumption of the house hold anbaris producers that earthen vessel produced anbaris which is different than anbaris produced utilizing neutral containers. Simply, earthen vessels are manufactured using clay, thus it allows the diffusion of water and salt and thus leads to lower moisture content and 
higher protein content. This is in accordance with the results of Amasi, a fermented milk product in Zimbabwe, whose properties were found to be better when earthen vessels were used in comparison to amasi produced using glass jars [19] [21].

When comparing the labneh from cow's milk it had lower fat, protein ash, total solids and higher $\mathrm{pH}$ and moisture content. This is due to the fact that labneh from cows milk is strained for less than 7 day, 24 hours, in a cloth thus not as it is described usually in the production of labneh [22] which is not always practiced in the production of commercial cow's milk labneh. Since the 7 days straining period is practiced in goat and anbaris production the physicochemical properties were very comparable and in turn they were in accordance with values of labneh produced from cow's milk when 7 day straining was used [22].

\section{CONCLUSION}

Pasteurization did not affect the measured physicochemical properties of anbaris in this study, but a sensory analysis should be conducted to establish the profile for anbaris and other labneh products. The usage of earthen vessel is proven to lead to different anbaris product even at this level of testing. Comparing labneh from goat's, cow's milk origion and anbaris showed very similar physicochemical properties when straining time is applied. Thus, further tests should be conducted such as characterizing the different volatile compounds in the different labneh products.

\section{ACKNOWLEDGMENT}

Special thanks to MEFOSA, MENA Food Safety Associates, for providing the water activity testing equipment and their facility. Special thanks also for the food heritage foundation for providing us with the earthen vessels and their data base of contacts.

\section{REFERENCES}

[1] Tamime, AY. (2002). Fermented milks: a historical food with modern applications-a review. European Journal of Clinical Nutrition, 56(4), S2-S15.

[2] Tamime, AY, Wszolek, Monika, Božanić, Rajka, and Özer, Barbaros. (2011). Popular ovine and caprine fermented milks. Small Ruminant Research, 101(1-3), 2-16.

[3] Tamime, Adnan Y and Robinson, Richard Kenneth. (2007). Tamime and Robinson's yoghurt: science and technology: Elsevier.
[4] Şanlier, Nevin, Gökcen, Büşra Başar, and Sezgin, Aybüke Ceyhun. (2019). Health benefits of fermented foods. Critical reviews in food science and nutrition, 59(3), 506527.

[5] Marco, Maria L, Heeney, Dustin, Binda, Sylvie, Cifelli, Christopher J, Cotter, Paul D, Foligné, Benoit, Gänzle, Michael, Kort, Remco, Pasin, Gonca, and Pihlanto, Anne. (2017). Health benefits of fermented foods: microbiota and beyond. Current opinion in biotechnology, 44, 94-102.

[6] Keceli, Turkan, Robinson, RK, and Gordon, MH. (1999). The role of olive oil in the preservation of yogurt cheese (labneh anbaris). International journal of dairy technology, 52(2), 68-72.

[7] Saleh, Hassan, Microbiological changes, chemical composition and sensory properties of Labneh anbaris made from cow's and goat's milk-by Hassan Saleh. 1991.

[8] Serhan, Mireille and Mattar, Jessy, The Goat Dairy Sector in Lebanon, in Goat Science. 2017, IntechOpen.

[9] Serhan, Mireille and Mattar, Jessy. (2013). Characterization of four Lebanese artisanal goat milk cheeses: Darfiyeh, Aricheh, Shankleesh and Serdale by physico-chemical, microbiological and sensory analyses. J. Food Agric. Environ, 11(3-4), 97-101.

[10] Dimassi, Ossama, Iskandarani, Youmna, Afram, Michel, Akiki, Raymond, and Rached, Mohamed. (2020). Production and physicochemical properties of labneh anbaris, a traditional fermented cheese like product, in Lebanon. International Journal of Environment, Agriculture and Biotechnology, 5(3).

[11] ISO5537, Dried milk - Determination of moisture content (Reference method), in ICS > $07>07.100>07.100 .30$, International Organization for Standardization;, Editor. 2004: Geneva, Switzerland: .

[12] AOAC. (1990). 15th Edition, Association of Official Analytical Chemists, Washington DC.

[13] ADMI, Chicago. (1971). Standards for Grades of Dry Milk including Methods of Analysis. Bulletin, 916.

[14] KJ Valentas, E Rotstein, RP Singh (1997). Handbook of food engineering practice: CRC press.

[15] Nielsen, S Suzanne, Sodium Determination Using IonSelective Electrodes, Mohr Titration, and Test Strips, in Food Analysis Laboratory Manual. 2017, Springer. p. 161170.

[16] Al-Kadamany, E, Toufeili, I, Khattar, M, Abou-Jawdeh, Y, Harakeh, S, and Haddad, T. (2002). Determination of shelf life of concentrated yogurt (Labneh) produced by in-bag straining of set yogurt using hazard analysis. Journal of dairy science, 85(5), 1023-1030.

[17] Food, U.S. and DrugAdministration. Acidified \& LowAcid Canned Foods Gudiance Documents \& Reg Information. U.S. Food and Drug Administration 2020 5/4/2020]; Available from: https://www.fda.gov/food/guidance-documents-regulatoryinformation-topic-food-and-dietary-supplements/acidifiedlow-acid-canned-foods-guidance-documents-regulatoryinformation. 
[18] Grappin, Rémy and Beuvier, Eric. (1997). Possible implications of milk pasteurization on the manufacture and sensory quality of ripened cheese. International Dairy Journal, 7(12), 751-761.

[19] Feresu, Sara and Muzondo, MI. (1989). Factors affecting the development of two fermented milk products in Zimbabwe. MIRCEN journal of applied microbiology and biotechnology, 5(3), 349-355.

[20] Barakat, Darine Emile, The effect of heat treatment and storage temperature on the microbiological and chemical qualities of traditional Labneh anbris-by Darine Emile Barakat. 2009.

[21] Gadaga, TH, Mutukumira, AN, Narvhus, JA, and Feresu, SB. (1999). A review of traditional fermented foods and beverages of Zimbabwe. International journal of food microbiology, 53(1), 1-11.

[22] Rao, DR, Alhajali, A, and Chawan, CB. (1987). Nutritional, sensory and microbiological qualities of labneh made from goat milk and cow milk. Journal of food science, 52(5), 1228-1230. 